\title{
Bibliography: selected manuscript sources
}

\section{BODLEIAN LIBRARY, OXFORD}

Bankes MSS

Cherry MSS

Clarendon MSS

Nalson MSS

Rawlinson MSS

\section{BRITISH LIBRARY}

\section{ADDITIONAL MSS}

${ }_{15} 671$ Minutes of orders of Commons relating to the Committee for Plundered Ministers

17677 Correspondence related to England ... from the Archives at the Hague

28003 Oxinden correspondence

29974 Pitt correspondence

31116 Diary of Lawrence Whitaker

32683 Sidney correspondence

34014 Returns by the Major Generals, 1655

34016 Names of persons living in Westminster ... 1655

38856 Hodgkins MSS

70005 Portland MSS

78364 Evelyn papers

\section{HARLEIAN MSS}

832 Collection of papers relating to the creation of St Paul Covent Garden

1831 Register book made by the burgesses and assistants of Westminster, c. 1660

\section{CAMBRIDGE UNIVERSITY LIBRARY}

MS Gg/1/9 List of members of Westminster Court of Burgesses, high bailiffs, stewards, high constables, and other minor officials, 1639-6o

\section{CHRIST CHURCH, OXFORD}

MS 451 Notes on sermons given at St Margaret Westminster

$$
\text { DOCTOR WILLIAMS'S LIBRARY }
$$

Baxter Letters 
DURHAM UNIVERSITY LIBRARY

John Cosin Letter Book

HOUSE OF LORDS RECORD OFFICE

Main Papers

HUNTINGTON LIBRARY, SAN MARINO, CALIFORNIA

Ellesmere MSS

\section{LAMBETH PALACE LIBRARY}

COMM XIIa/12 Interregnum valuations of clerical stipends

LONDON METROPOLITAN ARCHIVES

Journals of the Court of Common Council

Repertories of the Court of Aldermen

MIDDLESEX SESSIONS

MJ/SBR Sessions of the peace registers, 1608-1667

$\mathrm{MJ} / \mathrm{SR}$ Middlesex sessions of the peace rolls

MJ \& WJ/SB/B Westminster sessions books

WJ/SR Westminster sessions of the peace rolls, 1620-1844

QUEEN'S COLLEGE, OXFORD

MS 77 Register of the Westminster Military Company, 1622-39

SHEFFIELD CITY ARCHIVES

Strafford Papers

Elmhirst Pye Papers 1287 (c)

\section{SHEFFIELD UNIVERSITY LIBRARY}

Hartlib Papers

THE NATIONAL ARCHIVES, LONDON

C5 Chancery Proceedings

C193 Libri Pacis

E179 Exchequer, King's Remembrancer, Lay Subsidies (assessments, certificates, etc.)

E317 Parliamentary Surveys

PC2/41-52 Privy Council Registers (June 1631-September 1640)

PCC/Prob 11 Prerogative Court of Canterbury, Will Registers

$\mathrm{SP} 16 \quad$ State Papers Domestic, Charles I

$\mathrm{SP} 20 \quad$ Sequestration Committee, books and papers 
$\mathrm{SP} 25 \quad$ Council of State, books and accounts

$\mathrm{SP}_{2} 8 \quad$ Commonwealth Exchequer papers

SP29 Secretaries of State: State Papers Domestic, Charles II

$\mathrm{SP}_{4} 6 \quad$ State Papers Domestic, Supplementary

\section{WESTMINSTER ABBEY MUNIMENTS}

3922

5271

6568

9352

9357

9359, 9377

9363, 9379, 9407

9366

9381

9401

9633

9678

9888

$24850,24852,24855$,

$42268,42506-7$

24851

$24995-6,25005,42827$

25109

33422
Seal of the Governors of the School and Almshouses of Westminster

Petition for a place in the almhouses, n.d. Order of parliament dated 12 October 1652 for granting the royalties of Westminster

Petition to the Governors not to farm out the royalties of Westminster, n.d.

Petition requesting use of Henry VII chapel for a Sunday afternoon lecture, n.d.

Petitions concerning failure to provide communion in Abbey church, (later 1640s)

Petitions concerning Knightsbridge chapel, 1646 and n.d.

Testimony of Elizabeth Whitney concerning John Binns, November 1648

Petition for maintenance for a minister for Tothill Fields chapel, n.d.

Petition of Samuel Gibson, minister of St Margaret Westminster, n.d.

Letter from the earl of Pembroke to Committee for the College of Westminster, 1647

Petition of John Arnold touching appointment of bailiff of sanctuary, n.d.

Petition of burgesses and assistants of Westminster to Governors of School and Almshouses on behalf of Thomas Latham, n.d.

Payments for new pews, construction of new gallery, $1645-46$

Seating plan of pews in the Abbey, temp. Commonwealth

Petitions touching pews, 1649,1650

Memorandum of the appointment of a royal commission to hold a visitation of Westminster college

Deputy receiver's accounts, $1654-56$ 
$42733,42796,42799-$

$800,42802 \mathrm{~A}, 4^{2803^{-13}}$ Orders for the security of Westminster Abbey, c. 1650

42750-64 Work on the dean's house, 1650 os

42827

Petition touching lack of seats for members of the Court of Burgesses and their wives, 1649

42908A, 42991-3,

43506,43857

Orders signed by John Bradshaw as Governor of the School and Almshouses

\section{WESTMINSTER ARCHIVES CENTRE}

\section{ST CLEMENT DANES}

B11 Churchwardens' accounts $1633-54$

B12 Churchwardens' accounts 1654-70

B24/A48 Accounts, overseers for the poor $1627-50$

B25/A48 Accounts, overseers for the poor 1650-63

ST MARGARET WESTMINSTER

E23-40 Churchwardens' accounts 1640-60

E154-174 Accounts, overseers for the poor 1640-1661

E2413 Vestry minutes 1591/2-1661/2

ST MARTIN IN THE FIELDS

F3-16 Churchwardens' accounts 1624-60

$\mathrm{F}_{3} \mathrm{G}_{1-3} 87$ Accounts, overseers for the poor $1635-60$

F2002 Vestry minutes 1624-52

F2003 Vestry minutes 1652-65

ST MARY LE STRAND

Vol. 22 Churchwardens' accounts 1586-1650

G2 Accounts, overseers of the poor and churchwardens 1625-55

ST PAUL COVENT GARDEN

H433-441 Accounts, overseers for the poor 1647-1660

426/134-136 Churchwardens' accounts 1656-1662 